\title{
An-Natiq
}

Jurnal Kajian Islam Interdisipliner

Volume 01 Nomor 02 Tahun 2021

e-ISSN: 2777-0176 | p-ISSN: 2798-0200

\section{ISU SOSIO-HISTORIS DALAM TAFSIR AL-QUR'AN AL-KARIM}

\author{
Ahmad Nabil Amir \\ International Institute of Islamic Thought and Civilization (ISTAC-IIUM) \\ e-mail: nabiller2002@gmail.com
}

\begin{abstract}
This paper discusses political and social issues in kitab Tafsir al-Qur'an alKarim penned by al-Ustaz H. A. Halim Hasan, H. Zainal Arifin Abbas dan Abdur Rahim Haitami. Kitab Tafsir al-Qur'an al-Karim by these trio scholars was among the pre-eminent works of contemporary tafsir in Indonesia acclaimed for its balanced method of commentary using transmitted narrative (al-naql) and rational judgement (al-'aql) in commentary. Some crucial issues of politics addressed were justice, democracy, shura (consultation) and freedom while social issues treated were hypocrisy, history of the Children of Israel, prophethood, natural disposition, intercession, mysticism and arrangement of nature. The method was descriptive and analytical in highlighting political and social views brought forth in the Tafsir. The finding shows that the political and social issues addressed in this work have been significantly established. The accomplishment has positive implication in the development and reform of tafsir in modern times that critically assist in the religious movement for social justice and political reform in Indonesia.
\end{abstract}

Keywords: Tafsir al-Qur'an al-Karim, H. A. Halim Hasan, issue, politics, social

\section{A. Pendahuluan}

Kitab Tafsir al-Qur'an al-Karim adalah karya tafsir moden yang dikerjakan oleh al-Ustaz H. A. Halim Hasan, H. Zainal Arifin Abbas dan Abdur Rahim Haitami di Medan. Ia mengupas idealisme politik dan sosial dan faham islah yang dibawa dalam karya-karya tafsir modernis di Timur Tengah. Ia merupakan antara karya tafsir muktabar yang menegakkan faham dan ide pembaharuan yang dilakarkan oleh Shaykh Muhammad Abduh dan Muhammad Rasyid Rida dalam Tafsir alManar. Latar penulisannya yang menarik dan kekuatan analisis yang ditampilkan dalam mengembangkan aliran Islam moden telah memberikan kesan dan pengaruh yang luas dalam tradisi pemikiran dan peradaban Islam yang progresif di rantau ini. Kertas ini berusaha untuk membincangkan isu-isu politik dan sosial yang diketengahkan dalam karya ini dan melihat pengaruhnya kepada aliran pembaharuan dan kebangkitan tafsir modernis di nusantara. 
Sumber utama yang diacu dalam Tafsir ini adalah Tafsir al-Manar yang dihasilkan oleh Sayid Muhammad Rashid Rida dan Shaykh Muhammad 'Abduh, serta tafsir al-Jawahir fi Tafsir al-Qur'an al-Karim oleh Faylasuf Islam Tantawi Jawhari, di samping mengutip hujah-hujah yang didengungkan oleh penafsirpenafsir berhaluan modern yang lain seperti Tafsir al-Maraghi oleh Shaykh Muhammad Mustafa al-Maraghi dan aliran-aliran klasik dan tradisional yang lain. Nukilan yang substantif dari kitab Tafsir al-Manar ini memperlihatkan pengaruh yang jelas dari idealisme reform yang dikembangkan oleh Shaykh Muhammad Abduh dalam perjuangan kaum muda di Indonesia, seperti diungkapkannya: "Kemudian, untuk memudahkan faham atasnya, dan untuk menolong kita memberikan gambaran-gambaran yang nyata mengenai ayat-ayat tersebut, yang sesuai dengan perkembangan ilmu-ilmu pengetahuan pada zaman kita ini, kami uraikan pula dengan berpedomankan Tafsir al-Manar yang mulanya dikarang oleh al-Ustazul Imam Syeikh Muhammad Abduh iaitu sampai djuz II, dan kemudian diteruskan oleh murid beliau, Sayid Muhammad Rasyid Rida tetapi dengan berpedomankan pengajaran-pengajaran yang telah diterimanya dari al-Ustazul Imam Syeikh Muhammad Abduh juga adanya sampai akhir surat Yusuf (as) (juz xii-xiii)." (H. A. Halim Hassan, et al., 1960, juz. 2/h. 7) [Cet. v.]. Dalam perbincangan ayat-ayat yang musykil dan mutasyabih, asbab al-nuzul dan istinbat hukum, ia menukil hujah dari tafsir klasik seperti Imam Ibn Jarir al-Tabari, al-Tha'labi, alBaghawi, al-Khazin, Ibn al-'Arabi, Abi al-Su'ud, Abu Tahir b. Ya'qub al-Fairuzabadi, dan Ibn Kathir yang meraikan pandangan mazhab dan pemikiran sunni yang muktabar. Rujukan yang ekstensif terhadap kitab-kitab tafsir klasik ini dicatatkan dalam muqaddimah kitab Tafsir al-Qur'an al-Karim ini: "Tafsirkan pertama kali berdasarkan keterangan-keterangan (uraian-uraian) yang terdapat di dalam kitabkitab tafsir yang tertua, dengan mengutamakan pendapat-pendapat yang lebih tertua di antara ahli-ahli tafsir kita yang muktabar itu (Ibn Jarir, Razi, Ibn Kathir, al-Baidawi)." (H. A. Halim Hassan, et al., 1960, juz. 2/h. 7).

Tafsir ini turut menyorot pemikiran tasawuf yang dibawakan dalam tafsir sufi dan isyari seperti Tafsir al-Tustari dan Lata'if al-Isyarat oleh al-Qusyairi. Ia turut membahaskan usul mazhab dan aliran bahasa (nahu) dan qira'at dengan mengutip perbincangan dari kitab Mu'jam Gharibil Qur'an oleh Muhammad Fu'ad 'Abdul Baqi, Mu'jam al-Qur'an oleh al-Mahamy 'Abdul Ra'uf al-Mishry (Abu Rizq), dan Tafasil ayat al-Qur'an oleh Jule Le Baume (orientalis Perancis).

Dalam menangani banyak persoalan ijtihad dan aliran fiqh Islam, ia menyorot pandangan ulama muta'akhir di kalangan pentafsir al-mu'asir seperti Muhammad Farid Wajdi dalam kitabnya al-Mushaf al-Mufassar, A. Hasan Bandung dalam Tafsir al-Quran (al-Furqan) dan Muhammad Mahmud Hijazi dalam Tafsir al-Wadih. 


\section{B. Tema dan Manhaj}

Corak tafsir yang dibawa adalah berasaskan aliran adabi ijtima'i (sastera budaya) dan manhaj haraki dan islah yang diilhamkan dari Tafsir al-Manar. Kekuatan Tafsir al-Qur'an al-Karim ini adalah dalam rumusan dan tafsiran sosialnya yang khas. Kupasannya diperkukuh dengan perbahasan yang ekstensif terhadap idealisme dan fikrah moden yang digagaskan oleh Shaykh Muhammad 'Abduh dan Sayid Muhammad Rashid Rida. Ia merupakan antara tafsir kontemporer yang terkesan meraikan kefahaman teks klasik dan moden dalam penelitian tafsir yang merangkul paham dan aliran al-ra'y dan al-ma'thur.

Pertimbangannya juga turut mengartikulasikan pendapat dan pendirian pentafsir-pentafsir moden seperti Ahmad Mustafa al-Maraghi dalam Tafsir alMaraghi, dan Ignaz Goldziher dalam Mazahib Tafsir Islamy dalam banyak isu yang kontroversil. Ia cuba menzahirkan pandangan pentafsir moden dan kejituannya dalam memahami makna dan konteks ayat yang dibincangkan.

Tafsir ini menangani banyak isu dan tema yang penting. Ini dipaparkan dalam perbahasannya tentang tema-tema dasar tentang mazhab hukum, ijtihad, semangat jama'ah, jihad, percaturan alam, kebebasan intelek, fitrah dan hubungannya dengan masyarakat Indonesia, dan hal-hal yang terkait dengan isu kewanitaan, fikrah pembaharuan, kejumudan, kebebasan akliah dan lain-lain. Tema-tema yang signifikan yang diangkat dalam tafsir ini memberikan refleksi yang jelas terhadap pandangan hidup umat Islam di Indonesia dan latar penghidupan dan tekanan politik yang dihadapi terhadap perkembangan dakwahnya di bawah cengkaman penjajah. Tafsir ini telah mengilhamkan kebangkitan dan pencerahan yang jelas yang mempengaruhi angkatan baru Islam dari golongan ulama dan intelektual di Indonesia, termasuk Buya Hamka yang merujuknya dalam penulisan Tafsir al-Azhar. Kaitan yang jelas antara para pentafsir ini dengan Buya Hamka dirakamkan dalam bukunya, Kenang-Kenangan Hidup: "Hamka San datang ke majlis itu dengan temannya iaitu $\mathrm{Hj}$. Abdul Halim Hassan dari Binjei, Zainal Arifin Abbas, Abdurrahim Haitami; ketiga-tiga mereka ini ialah pengarang Tafsir al-Qur'an yang terkenal, sedang yang pertama adalah martabat guru dari yang berdua." (Hamka, 1966, h. 395). Permasalahan teologi turut dibahaskan dalam Tafsir ini yang mengungkapkan prinsip dan usul aqidah berkait dengan ilmu kalam, qada' dan qadar, tawakal, ikhtiar, pegangan mazhab, faham akal dan wahyu, falsafah agama, polemik dan pembenturan antara mazhab. Persoalan berkait dengan keyakinan dan prinsip aqidah yang fundamental ini 
dicerakinkan dalam Tafsir Shaykh Muhammad Abduh, seperti yang dikutip oleh pentafsir: "Fatihah itu dibaca 17 kali dalam sehari semalam. Tak lain tak bukan sebagai cemeti pelecut kita agar kita tahu bagaimana berlaku terhadap Tuhan kita. Tidaklah semata-mata mesti berserah kepada-Nya dengan meninggalkan usaha dan ikhtiar kita. Tetapi kita lakukanlah dahulu usaha-usaha dan ikhtiar-ikhtiar kita, barulah kita meminta bantuan dan pertolongan kepada-Nya di dalam segenap hal. Tetapi sebaik-baiknya meminta pertolongan itu sewaktu mengerjakan ta'at dan kebajikan." (Tafsir Surah al-Fatihah, ayat 5), (H. A. Halim Hassan, et al., 1960, juz $1 / \mathrm{h} 49$ ). Ia turut membawa polemik yang menyentuh tentang akidah dan manhaj kalam Asha'irah yang berbeza dengan ideologi dan sudut pandang puak Mu'tazili, Jabari, Qadari, dan Shi'i.

\section{Isu-Isu Tafsir}

Antara isu-isu yang diketengahkan mencakupi perhubungan ayat awal dan akhir, asbab nuzul, ibarat-ibarat dalam al-Qur'an, sunnah Allah swt terhadap hambaNya, filsafat kaya miskin, qiblat, Islam dan Nasrani, karakteristik Yahudi, jihad, khittah dakwah, berhala - macam-macam sekutu, sebab-musabab (pentafsir merumuskan pandangannya tentang hubungan sebab dan akibat: dalam menuntut sesuatu hendaklah dituntutnya dengan mengerjakan sebab-sebabnya), dunia akhirat, i'tiqad, kemerdekaan berfikir, budaya taqlid, sejarah perjuangan Bani Isra'il, harakat islah dan akhlak dan adab-adab Islam, kekuatan usul mazhab syafi'i, serta perjalanan sirah Rasulullah (saw). Yang menarik dalam kupasannya adalah penegasan aliran modernis dan klasik yang tercantum dalam komentarnya yang ekstensif terhadap ayat-ayat al-Qur'an, suatu upaya untuk mengangkat dan meraikan mazhab al-ra'y dan al-ma'thur dalam pendekatan tafsir. Ia menampilkan fikrah dan aspirasi moden yang diperjuangkan Sayid Jamal al-Din al-Afghani, Shaykh Muhammad 'Abduh dan Sayid Muhammad Rashid Rida, dan menggariskan idea rasional dan progresif yang diilhamkannya.

Isu-isu yang signifikan yang diangkat telah mencetuskan pandangan baru dalam pemahaman teks al-Qur'an di rantau Melayu. Ia menzahirkan kesedaran moden dan semangat rasional yang digarap dalam Tafsir al-Manar. Ini diketengahkan dalam perbahasan seputar isu-isu sosial budaya menyangkut kebobrokan budaya taqlid, dan posisi umat Islam di Indonesia dan kekusutan agama dan politiknya yang morat marit di bawah tekanan penjajah, dan perjuangan 'kaum muda' untuk merobah struktur masyarakat.

Isu-isu ini dibincangkan secara komprehensif berdasarkan nas al-Qur'an dan al-hadith, yang diimbangi dengan perbandingan dan nukilan dari kitab-kitab tafsir yang lebih awal. Fokus yang tuntas dihalakan pada kebangkitan sosial dan agama dan keadaan kehidupan umat Islam yang terkebelakang di Indonesia. 
Perbincangan yang jitu tentang isu-isu yang kritis ini memperlihatkan kepentingannya yang krusial dalam sejarah moden. Isu-isu ini dibincangkan secara dekat dengan penekanan yang tuntas terhadap aspirasi kebebasan dan perjuangan umat Islam di Indonesia.

\section{Isu politik}

Isu politik yang dikemukakan dalam Tafsir al-Qur'an al-Karim ini mengupas persoalan demokrasi dan negara hukum. Ia menganalisis tafsiran fuqaha tentang prinsip syura, dan kebijakan hukum yang digariskan dalam pemerintahan. Perbahasan yang kritis turut dilakarkan tentang prinsip khalifah dan dawlah serta isu-isu politik yang mendasar. Perbincangannya adalah berdasarkan kitab-kitab klasik yang menghuraikan petunjuk al-Qur'an tentang kerangka politik Islam seperti yang dirumuskan dalam tradisi akliah yang berkembang dari pemikiran dan penafsiran ortodoks seperti Ahkam al-Sultaniyyah wal-Wilayah al-Diniyah oleh al-Mawardi, Madinah al-Fadilah oleh al-Farabi, Tafsir al-Kabir oleh Ibn Taimiyah, dan Tafsir al-Qur'an al'Azim oleh Ibn Kathir. Kupasan yang menarik dikemukakan tentang idealisme hukum, kefahaman demokrasi, tuntutan jihad, tata urus kerajaan dan perbincangan yang substantif tentang prinsip musyawarah.

\section{Keadilan}

Prinsip negara hukum yang dikemukakan dalam tafsiran ulama dan fuqaha Islam, dalam kerangka besarnya, dapat dirumuskan dari tafsiran Shaikh Muhammad Rashid Rida dalam kitabnya al-Khilafah al-Uzma: "The land of justice, which is the Land of Islam, is a land that has a true leader who establishes justice. This is contrary to the 'land of injustice and aggression', in which governorship is based on some 'ethnic solidarity' ('asabiyyah), practiced by some Muslims, regardless of the establishment of the Islamic rulings." (Muhammad Rashid Rida, 1922, h. 50) [Wilayah keadilan, yang merupakan wilayah Islam, adalah wilayah yang mempunyai pemimpin yang sebenar yang menegakkan keadilan. Ini bertentangan dengan 'wilayah kezaliman dan keagresifan', di mana kerajaan didasarkan kepada 'solidaritas etnik ('asabiyyah), yang diamalkan oleh sebahagian Muslim, tanpa mengira pelaksanaan hukum 
Islam di dalamnya]. Al-Mawardi turut menekankan kepentingan mengangkat pemimpin yang layak dan bermoral, dan sanggup menegakkan keadilan. Beliau menulis: "People who are qualified to make decisions in the Land of Justice should choose a leader who possesses a good character and competency." (AlMawardi, 'Ali b. Muhammad 2006, vol.1, h.22). [Kalangan yang layak menentukan dan membuat keputusan dalam Negara Keadilan harus memilih pemimpin yang mempunyai karakter yang mulia dan berwibawa].

Ibn Taimiyah mengungkapkan bahawa "justice is the universal law of things" [keadilan adalah undang-undang universal bagi setiap benda] (Ibn Taymiyah, Ahmad ibn 'Abd al-Halim, 2004, vol.28, h.146). Beliau menganggap 'pencapaian keadilan' dalam sebuah negara sebagai upaya yang paling fundamental, dan layak mendapat dukungan Tuhan, walaupun bagi 'golongan yang tidak beriman'. Beliau menulis: “In this life, people prevail when justice prevails in their society even if they fall into various kinds of sins. However, people will not prevail when injustice and lack of rights prevail in their society." (Ibn Taymiyah, Ahmad ibn 'Abd al-Halim, 2004, vol.28, h.146) [Dalam kehidupan ini, manusia berjaya apabila keadilan ditegakkan dalam masyarakat mereka meskipun mereka terbenam dalam pelbagai bentuk dosa. Bagaimanapun, manusia tidak akan berhasil apabila ketidakadilan dan penghakisan hak bermaharajela dalam masyarakat mereka].

Prinsip keadilan merupakan teras kepada maqasid al-shariah dan asas dan tiang penting dalam sistem politik yang mempan dan kukuh. Kitab Tafsir alQur'an al-Karim ini menyajikan analisis yang substantif tentang prinsip dan falsafah dalam pembentukan sesuatu negara hukum. Ia merujuk secara ekstensif kepada Tafsir al-Manar yang mengupas isu yang berkait dengan amalan politik yang menggarap makna dan gagasan yang dilontarkan tentang fiqh dawlah dan siyasah shar'iyyah. Shaikh Rashid Rida merumuskan kefahaman dan kerangka asas sistem kebebasan yang mempertahankan nilai keadilan yang mendasar: 
"Indeed, many countries that are governed by Muslim leaders are countries where one is forced against practicing his/her religion and cannot reveal everything he/she believes in or fulfils his/her practical Islamic obligations, especially enjoining good, forbidding evil, and the ability to criticize rulings that go against the Divine Law. This land, according to some scholars, is a 'Land of War'." (Jasser Auda, 2012) [Malah, kebanyakan negara yang diperintah oleh pemimpin Islam adalah negara di mana seseorang dihalang dari mempraktiskan agamanya dan tidak dapat menzahirkan setiap sesuatu yang diyakininya atau menyempurnakan tanggungjawab Islamnya yang praktikal, terutamanya menyuruh kepada yang makruf, menegah kejahatan, dan kesanggupan untuk mengkritik pemerintah yang menyalahi perintah wahyu. Wilayah ini, menurut sebahagian ulama, adalah 'Wilayah Perang'] (Kritik dan kefahaman yang lebih jelas terkait dengan prinsip dan siyasah Islam ini dapat dirujuk dari Al-Sarakhsi, al-Usul, vol.9, p. 182, AlKasani, Bada'i` al-Sana'i’, vol.7, p.80, Ibn Qudamah, Al-Mughni, vol.9, p.14, AlNawawi, Rawdat al-Talibin, vol.10, p.49, Al-Zar`i, Al-Jawab al-Kafi, vol.1, p.101, Ibn Abidin, Hashiyat Raddul-Mukhtar, vol.4, p.45, Al-Alusi, Ruh alMa'ani, vol.18, p.91, Nizam, Al-Fatawa al-Hindiyah, vol.2, p.179)

Dalam mendefinisi negara Islam, Muhammad Asad menggariskan bahawa negara Islam adalah "suatu negara yang asas politiknya amat berbeda dengan model-model yang ada di penjuru dunia saat ini - yang sama sekali tidak dibangun di atas prinsip-prinsip nasionalisme maupun golongan, melainkan semata-mata berdasarkan al-Qur'an dan sunnah Rasul (saw)." (Muhammad Asad, 1987, h. ix). Dalam tafsiran ayat 51, surah al-Baqarah, kitab Tafsir ini membahaskan peranan Nabi (saw) untuk melanjutkan warisan para anbiya' (as) dalam menyampaikan risalah kewahyuan, termasuk menggariskan dasar politik yang adil: "Kewajipan Rasulullah (saw) mengajarkan ayat-ayat Allah, menerangkan hikmat-hikmat dan mengajarkan apa-apa yang belum diketahui oleh ummat itu, seperti dari hal mengadili perkara, dari hal politik dan 
mengendalikan urusan pemerintahan negeri." (H. A. Halim Hassan, et al., 1960, 1/56).

Pada perbahasan ayat 143 dari surah al-Baqarah: "Supaya kamu menjadi saksi atas manusia" turut dibahas prinsip keadilan sebagai teras hukum dan syariat: "Yang ada dalam ayat $143 \mathrm{ini}$, artinya: "Supaya kamu menunjukkan kepada segenap bangsa manusia akan kebaikan dan kemurnian agama kamu dengan melakukan dan membuktikan keadilan dan pertengahan di dalam segenap pekerjaan agama kamu." (H. A. Halim Hassan, et al., 1960, 2/41)

\section{Demokrasi}

Demokrasi adalah "sistem kerajaan oleh rakyat berbanding oleh satu individu atau kelompok elit. Ia boleh dimaknakan sebagai kerajaan oleh sokongan populis; suatu bentuk kerajaan yang mana kuasa tertinggi terletak kepada rakyat dan dikendalikan secara langsung oleh mereka atau oleh perwakilan mereka yang dilantik secara bebas." (J. Paul Barker, 2011). Menurut Muhammad Asad, semangat dan falsafah demokrasi di Barat seyogianya didakap, kerana ia mewakili politik moderat yang menolak dua kutub ekstrim, diktatorial yang bercorak ortodoks, dan liberal moden, kerana: "yang kita butuhkan adalah penyusunan konstitusi Islami dalam 'satu kata' yang sekaligus dapat menjawab tuntutan-tuntutan yang ada sekarang ini." (Muhammad Asad, 1987, h. xi).

Sistem demokrasi menuntut sebuah pemerintahan yang berteraskan hukum dan negara madani, seperti ditegaskan dalam deklarasi pilihanraya Freedom and Justice Party, Mesir: "The State is civil and civilian, for the Islamic State is civilian in nature (Negara adalah madani dan merangkul aspirasi sivil, kerana negara Islam adalah madani secara alami). (Freedom and Justice Party [FJP], 2011).

Dalam tafsir ayat 244, surah al-Baqarah, dirumuskan prinsip-prinsip sivil, asas demokrasi yang mempertahankan nilai hukum, dan kepedulian kepada rakyat: "Setiap ummat itu mempunyai dua tanggungjawab. Pertama menyiapkan tata tertib dalam negeri. Kedua mempertahankan keselamatan dari 
serangan luar dan kekacauan dalam negeri." (H. A. Halim Hassan, et al., 1960, 2/466).

\section{Shura}

Shura, bermaksud konsensus atau permuafakatan bersama. Ungkapan ini bertemu dalam al-Qur'an sebanyak tiga kali sebagai tercantum dalam surah 2: 233, 3: 159, 38:42. Perbincangannya memberi kefahaman yang positif, yang mengisyaratkan pada keputusan bersama dalam hal penyusuan anak, dan kerjasama dalam menangani urusan masjid, harakat Islam, dan dalam konteks semasa tentang pemilihan wakil parlimen melalui saluran demokrasi. Al-Qur'an menganjurkan proses dan amalan syura yang murni dan selari dengan acuan umum. Aspirasi dan konsep shura ini dibahas dengan kritis dalam Tafsir ini, dengan mengambil ikhtisar dari tafsiran klasik, seperti yang terakam dalam tafsir surah 2: 233: "Maka jika kedua (ibu-bapanya) berkehendak memperhentikan (anaknya daripada menyusu) dengan kesukaan di antara keduanya dan musyawarat, maka tiada dosa atas keduanya."

Pentafsir menghuraikan kepentingan bermusyawarah dalam segenap hal, khususnya dalam urusan yang menyangkut tentang dasar pemerintahan: “Di sini dapat juga kita menilik bagaimana agama Islam telah menyuruh kita memusyawaratkan sesuatu pekerjaan walaupun dalam pekerjaan yang seperti ini, apatah lagi umpamanya kalau bergantung dengan urusan yang besar-besar seperti pekerjaan yang bersangkut dengan kepentingan umat." (H. A. Halim Hassan, et al., 1960, juz II, h. 426).

\section{E. Isu Sosial}

Persoalan sosial yang diangkat dalam Tafsir ini menzahirkan kondisi sosial umat Islam di Indonesia dan cabaran dan tentangan-tentangan kebudayaannya yang dinamik. Kehidupan sosial ini memperlihatkan kesan dari pertarungan antara kaum muda dan tua dan pergolakan agama dan pikiran dan keyakinan yang diasak oleh dakyah kaum imperialis dan fahaman kristian dan infiltrasi paham sosialis, komunis dan nasionalis. Tafsir al-Qur'an al-Karim ini mengungkapkan ide yang 
berkesan bagi menjawab permasalahan sosial dan intelektual yang timbul oleh infiltrasi budaya, dan cita-cita pembaharuan yang digerakkan, dengan merujuk kepada karya-karya tafsir yang muktabar seperti kitab Fath al-Qaqir oleh Imam Muhammad b. 'Ali b. Muhammad b. 'Abdullah al-Syaukani al-San'ani (w. 1250 H.), Tafsir al-Jalalayn oleh Imam Jalaluddin al-Mahally, dan Jalaluddin al-Suyuti (w. 911 H), Anwar al-Tanzil wa Asrar al-Ta'wil oleh al-Qadi Abu Sa'id 'Abdallah b. 'Umar alBaidawi, Tafsir al-Kashshaf oleh Imam Abul Qasim Mahmud ibn 'Umar alZamakhshari, Ghara'ib al-Qur'an oleh Nizamuddin al-Hasan al-Naisaburi, alFutuhat al-Ilahiyah oleh Syeikh Sulaiman Jamal dan sebagainya.

Persoalan pokok yang dibincangkan adalah kemungkinan mencapai struktur sosial yang mencakup makna keadilan bagi seluruh kelompok sosial seperti yang dijelaskan dalam al-Qur'an. Muhammad Asad dalam karyanya Islamic Constitution Making, menjelaskan tentang dasar perhubungan sosial dalam Islam:

"Sistem sosial dalam Islam menawarkan alternatif-alternatif pemecahan yang mampu menjawab segala macam persoalan yang ada di semua kurun waktu, dan mampu berjalan seirama dengan perkembangan perjalanan ummat manusia." (Muhammad Asad, 1987, h. ix).

Ia mengetengahkan banyak isu sosial yang penting yang digarap dan dirumuskan dari faham sosial yang luas, yang menyentuh tentang keadilan masyarakat, persamaan ekonomi, tuntutan dakwah, budaya menurut (taklid buta), kefahaman agama yang rasional, memperkasa ruh jama'ah dan perjuangan islah. Ia memaparkan perbincangan falsafah yang ringkas yang disorot dari kerangka sosial yang luas dan kesan-kesannya dalam penghidupan dan pembentukan aspirasi sosial yang ideal. Ini dikemukakan dari perbincangan tentang sejarah, nubuwwah, fitrah, syafaah, ijtihad, kemunafikan dan lain-lain.

\section{Munafiq}

Munafiq (jamak munafiqun) menurut tafsiran Imam al-Shawkani, ialah "orang-orang yang menzahirkan Islam dan membatinkan kekafiran." (H. A. Halim Hassan, et al., 1960, 2/283 -keterangan ini dinukil dari tafsir al-Shawkani, Muhammad ibn-'Ali ibn-Muhammad, Fath al-qadir al-jami' bayn fannay alriwayah wal-dirayah min 'ilm al-tafsir). Para penulis Tafsir al-Quran al-Karim ini 
menghuraikan makna kemunafikan sebagai orang yang bermuka-muka: "Orang munafiqin yang bersifat kepala dua, melahirkan apa yang berlainan dengan yang di dalam hatinya dan mengakukan apa yang tidak pernah dilakukannya." (H. A. Halim Hassan, et al., 1960, juz 1/h. 54) (surah 2: 1-20).

Perbahasan yang terperinci tentang kefahaman ayat-ayat munafik ini, turut dikaitkan dengan karakter mukmin sebagai bandingannya, seperti yang dikemukakan pada tafsir ayat 207, surah al-Baqarah: "Dan setengah daripada manusia orang yang menjual dirinya karena menuntut keridaan-keridaan Allah, dan Allah sangat penyantun dengan hamba-hambanya," pentafsir menjelaskan: "Setelah panjang lebar dalam 3 ayat Tuhan menerangkan karakter orang yang manis mulut, tetapi busuk hatinya (munafiq), kemudian di sambung Allah dengan satu ayat lagi yang menerangkan sifat-sifat orang yang berlaku benar, ya'ni pepat di luar dan pepat juga di dalam, yang mengerjakan sesuatu karena menuntut keridaan Allah subhanahu-wa ta'ala." (H. A. Halim Hassan, et al., 1960, juz 2/h. 282).

Perbincangan tentang karakter dan kepalsuan dakyah munafik turut diangkat khususnya dalam perbincangan ayat-ayat Madaniyah dari surah alBaqarah. Dalam kupasannya pada ayat 143, surah al-Baqarah: "Dan tidak kami jadikan qiblat yang ada engkau (telah menghadap) atasnya itu melainkan supaya kami ketahui akan orang yang mengikut Rasul (saw) dari pada orang yang berbalik atas kedua tumitnya" pentafsir merakamkan pandangan yang dibawakan dalam Tafsir al-Manar: "Dan diketahui orang mu'min dalam fitnah ini, siapa yang tetap mengikut Rasul (saw) dan siapa orang yang munafiq, di mana kedua tumitnya telah dibalikkan oleh angin syubhat. Jikalau tiada dengan percobaan ini, tentu orang mu'min dengan orang munafiq tak dapat dibedabedakan, kerana mereka sekalian sama-sama mendirikan dan menunaikan 'amalan-amalan yang zahir yang dituntut Tuhan." (H. A. Halim Hassan, et al., 1960, 2/ 43-44).

Sikap yang diserlahkan kaum munafiq terhadap perintah menukar kiblat ini memperlihatkan keraguannya terhadap risalah Rasul (saw) dan 
keyakinannya yang telah terhakis terhadap wahyu, seperti yang dinyatakan pentafsir dari Tafsir al-Manar: "Dan ketika itu orang munafiq berkata pula: "(Nabi) Muhammad (saw) mula-mula sembahyang menghadap Baital Maqdis karena pujukan dari ahli kitab. Kemudian karena cintanya kepada tanah airnya dan karena hendak membesarkan tanah watannya itu, kembali pula ia menghadap ke Ka'bah. Nyatalah (Nabi) Muhammad (saw) itu seorang yang tidak tetap pendiriannya. Syubhat-syubhat yang hendak menyesatkan itu semuanya tidak berpengaruh pada diri orang mu'min. Orang yang tetap dan 'arif dalam keimanannya, hatinya rusuh dan kesal melihat manusia yang telah ragu bimbang dalam keimanannya itu. Sedang orang yang lemah keimanannya, imannya terus bergoncang karena terjadinya hal-hal itu." (H. A. Halim Hassan, et al., 1960., 2/42).

\section{Nubuwwah}

Soal kenabian, mukjizat, wahyu, kalam, risalah dan nubuwwah merupakan isu penting yang digarap dalam Tafsir ini. Kesinambungan risalah yang dibawa oleh para anbiya, dengan "kedatangan Nabi Muhammad (saw) menyempurnakan syariat-syariat yang dahuluan daripadanya (saw)" (H. A. Halim Hassan, et al., 1960, 1/372) hanya menyampaikan pesan tauhid yang sama. Nubuwwah dikaitkan dengan wahyu dan kenabian yang telah direncanakan Tuhan dalam ilmuNya. Dalam ayat 124, Surah al-Baqarah, Tuhan berkata kepada Nabi Ibrahim (as): "Sesungguhnya aku menjadikan engkau Imam (ikutan) bagi sekalian manusia.", pentafsir mengulas makna ayat yang menjelaskan pekerjaan yang dipikul ini tidak datang dari usahanya kerana hal kenabiannya itu atas pilihan dan tersebab ditunjuk: "(dinyatakan) (Fa qalal) sebab kalimah (qala) tidak mempunyai perhubungan, karena menurut penerangan Syeikh Muhammad Abduh, memberi ingat bahwa pangkat imam itu adalah semata-mata kurnia dari Tuhan dan pilihan-Nya, bukanlah lantaran menyempurnakan kalimah (perintah) itu. Sebabnya, karena Imam di sini ialah 'ibarat dari pada risalat (pangkat jadi rasul), sedang risalat itu tak dapat dicapai oleh usaha orang yang berusaha." (H. A. Halim Hassan, et al., 1960, 1/342). 
Tema seputar Nabi Ibrahim (as) banyak dikupas dalam Tafsir ini yang membincangkan keluasan pandangan tauhid dan kerangka dakwah Baginda (as) dan prinsipnya yang universal. Risalah yang suci ini (al-millah al-hanifiyah al-samhah) mempunyai makna dan kaitan yang rapat dengan kelompok "Yahudi dan Nasrani (yang) masing-masing mengatakan (Nabi) Ibrahim (as) dan anaknya memeluk agama mereka. (H. A. Halim Hassan, et al., 1960, 1/372).

Dalam tafsir surah al-Baqarah, ayat 124: "Dan ingatlah (ketika) Ibrahim (as) dicobai Tuhannya dengan beberapa kalimah (perintah), maka disempurnakannya sekalian itu. Berkata Allah: sesungguhnya aku menjadikan engkau "Imam" bagi segala manusia, "Berkata Ibrahim (as): "dan (begitu juga hendaknya) dari pada anak cucuku. Berkata Allah: "sekali-kali tidak mengenai perjanjianku itu akan orang-orang yang zalim", pentafsir menjelaskan peranan Nabi Ibrahim (as) sebagai imam dan pemula risalah samawiyah yang memberikan dampak yang signifikan dalam tradisi agama Yahudi, Nasrani dan Islam: "Kembali Allah membicarakan pembicaraan-pembicaraan yang lalu, yakni perihal yang berkenaan dengan Nabi Ibrahim (as)...suatu yang disandarkan kepadanya agama Islam dan Nabi orang Islam (saw), yang mana keduanya berasal dari satu pokok dan satu turunan yang sama-sama dibanggabanggakan oleh ahli kitab dan orang 'Arab, yaitu agama Nabi Ibrahim (as) dan keturunannya (as)." (H. A. Halim Hassan, et al., 1960 1/339).

Seterusnya dipaparkan tentang sejarah perjuangan Baginda (as) menyampaikan risalah Tuhan di Iraq, Mesir dan Palestin: "Cukuplah di sini kami sebutkan bahwa Nabi Ibrahim (as) itu segenap bangsa dan agama cukup kenal mengetahui dan mengakui kelebihan dan kemuliaannya. Sedang orang musyrik Makkah pun telah mengenal kemuliaan (Nabi) Ibrahim (as) dan mereka mengakui bahawa mereka berasal dari turunan anak sosial, yang mulia itu, sebagaimana mereka mengakui bahwa mereka mendiami tanah haramnya dan menjadi abdi yang berkhidmat untuk menjaga rumah tua, tempat ibadat yang telah didirikannya itu." (H. A. Halim Hassan, et al., 1960, 1/340). 
Pentafsir turut mengaitkan risalah Nabi Ibrahim (as) dengan keangkuhan yang dipamerkan oleh kaum Yahudi, yang menolak risalah Rasul (saw) yang terakhir, kerana mempertahankan faham asabiyyahnya yang sempit: "Allah Ta‘ala menyebutkan di sini cerita Nabi Ibrahim (as) supaya mereka semuanya sama-sama mempercayai dan mengimankan kerasulan Nabi Muhammad saw. Dalam ayat ini - kata Imam Fakhrur Razy dalam tafsirnya - ada beberapa hal yang perlu diinsafi orang Yahudi, Nasrani dan orang Arab musyrikin; Allah memerintahkan Nabi Ibrahim (as) agar menyempurnakan beberapa perintah...(hingga) tetaplah ia mencapai pangkat kenabian dan menjadi imam ikutan sekalian manusia. (H. A. Halim Hassan, et al., 1960, 1/340). Hal inilah yang perlu diinsafi oleh segenap orang Yahudi, Nasrani dan orang musyrik, bahwa kebajikan itu tidak akan dapat dicapai di dunia atau di akhirat melainkan haruslah lebih dahulu dengan meninggalkan sifat-sifat takbur dan durhaka; dan menjunjung sekalian hukum Allah dan taklif-taklif yang sudah diperintahkanNya.

Dalam tafsirannya terhadap ayat 241, Surah al-Baqarah: "Dan (ingatlah) seketika Ibrahim (as) dicobai Tuhannya dengan beberapa kalimah (perintah), maka disempurnakannya sekaliannya," pentafsir mengutip keterangan dari Tafsir al-Manar dan riwayat (athar) yang disandarkan kepada Ibn 'Abbas (as) yang menghuraikan makna kalimah yang diungkapkan dalam ayat tersebut: “Dalam Tafsir al-Manar ada tersebut bahwa Allah Ta'ala tak ada menerangkan kalimah-kalimah apa yang dicobakan-Nya atas Nabi Ibrahim (as) dan tidak diterangkan-Nya pula bagaimana cara-caranya Nabi Ibrahim (as) menyempurnakannya, karena orang Arab telah faham apa yang dimaksud dengan perkataan yang tersembunyi itu." (H. A. Halim Hassan, et al., 1960, 1/340).

Seterusnya dibahaskan makna "pengujian" menurut tafsiran Ibn 'Abbas (rad): "Yang dicoba, menurut kata Ibn 'Abbas (rad) yang dirawikan oleh 'Ikrimah (rah): tak ada seorang juga yang dicobai Allah (swt) dengan agama ini, yang terus sama sekali dikerjakannya, kecuali Nabi Ibrahim (as) yang telah diuji 
Allah dengan 30 macam percobaan dari pekerjaan-pekerjaan Islam. Ibn 'Abbas telah menetapkan: yaitu 10 dari surat al-Ahzab ayat 35, dan 10 dari surat alMu'min ayat 1 dan dari surat al-Ma'arij."

"Ada juga menyebut Nabi Ibrahim (as) dicobai Allah (swt) dengan 7 macam, yaitu dicobai dengan matahari, bulan, bintang, berkhitan di masa tua, dibakar, menyembelih puteranya Isma'il (as), dan dengan berhijrah meninggalkan tanah airnya ('Iraq); tafsir Abu's Su'ud." (H. A. Halim Hassan, et al., 1960, 1:341).

Pentafsir turut menukil pandangan Shaykh Muhammad Rashid Rida yang menyangkal tafsiran yang didasarkan dari riwayat Isra'iliyat tentang makna kalimah (perintah) dalam ayat tersebut: "Ada yang mengata yang dimaksud dengan kalimah di sini ialah perintah menyuruh berkumur-kumur (dan amalan fitrah yang lain), mengulas pandangan ini penafsir al-Manar menegaskan:

“Inilah satu keberanian yang amat heran terhadap al-Qur'an. Tak syak lagi pada saya bahwa inilah satu-satunya pengajaran yang telah diselipkan orang Yahudi kepada orang Islam, agar mereka menjadikan agamanya permainan. Di manakah agaknya kelemahan 'akal yang melebihi dari pada orang yang mengatakan seperti ini: "sesungguhnya Allah Ta'ala telah mencobai akan seorang Nabi (as) yang terkenal sebesar-besar Nabi (as) dengan pekerjaan-pekerjaan yang seperti ini, dan telah memuji pula atasnya kerana ia telah menyempurnakan pekerjaan-pekerjaan tersebut dan dijadikan-Nya pula perintah-perintah yang tersebut itu sebagai pendahuluan bagi keangkatannya akan menjadi imam bagi sekalian manusia dan menjadi usul bagi sedemikian itu, seandainya ditaklifkan kepada kanak-kanak yang sudah mumayyiz pun tentu dengan mudah sekali dapat disempurnakannya dan sudah tentu tidak akan disebutkan yang demikian itu suatu pekerjaan yang terlampau besar sekali. (H. A. Halim Hassan, et al., 1960, 1:341) 


\section{Fitrah}

Sunan atau "celupan Allah" pada lahirnya (literal) bermaksud ketentuan Allah (sunnat Allah) yang diatur sejak azali. Persoalan ini dibincangkan dalam konteks alam dan sifat lahiriah insan seperti yang dihuraikan pada tafsir surah al-Baqarah, ayat 246-47: "Sunnah Allah telah berlaku pula, selama sesuatu kaum mengingat Allah, selama itu pula kaum tersebut dimuliakan Tuhan, dan apakala kaum itu telah mengabaikan titahnya, maka kaum itu pun akan diganti Allah dengan umat yang lain, sebagaimana yang diperlakukan Allah terhadap kepada kaum Bani Israel." (H. A. Halim Hassan, et al., 1960, juz 1/369, juz 2/479) (Al-Baqarah, 2: 246-47).

Pada ayat 241, surah al-Baqarah: "Dan (ingatlah) seketika Ibrahim (as) dicobai Tuhannya dengan beberapa kalimah (perintah), maka disempurnakannya sekaliannya”, dihuraikan makna fitrah dari ungkapan 'kalimah' yang disempurnakan: "Ada yang mengata yang dimaksud dengan kalimah di sini ialah: perintah menyuruh berkumur-kumur, memasukkan air ke hidung, bersugi, menggunting kumis, menyikat (menyisir) rambut kepala, memotong kuku, mencabut bulu ketiak, mencukur rambut ari-ari, berkhitan dan istinja'." (H. A. Halim Hassan, et al., 1960, 1:340).

Balasan pahala dan siksa yang ditentukan Tuhan juga, menurut pentafsir, adalah suatu aturan alam juga: "Allah Ta'ala yang memiliki sekalian makhluk akan membalas mereka baik di dunia maupun di akhirat dengan memberi pahala pada orang yang ta'at dan beramal baik, menyiksa dan menghinakan segala orang yang pemalas dan durhaka. Dengan ini, seperti kata Tantawi, sempurnalah tarbiah dan peraturan 'alam." (H. A. Halim Hassan, et al., 1960, 1:47).

\section{Tasawwuf}

Perbincangan isu tasawwuf menghuraikan kesan dan pengaruh mistik dalam praktik Islam di Indonesia, serta falsafah dan khittah pemikirannya. Dan hubungannya dengan penafsiran-penafsiran mistik yang berpengaruh dalam ajaran-ajaran tariqat kesufian yang masyhur, seperti aliran al-Shadhiliyah, al- 
Akbariyah dan al-Qadiriyah. Perbincangan tentang mazhab dan tabaqat alsufiyyah ini diacu dari karya-karya sejarah al-Ustaz Zainal Arifin Abbas. Tafsirnya membahaskan pemikiran dan riwayat tafsir dan pengalaman ekstasi yang dirumuskan ulama-ulama sufi yang terkenal seperti Ibn al-'Arabi yang mempelopori faham wahdat al-wujud, dan pendirian pentafsir mengenainya.

Pentafsir mendukung aspek-aspek positif dari tasawwuf, dan menzahirkan keterbukaan pandangannya terhadap fikrah tasawwuf, dan peri pentingnya dengan kemajuan moden dan pembentukan pandangan hidup yang mendakap nilai kerohanian dan akhlak yang transenden, seperti dihuraikannya pada ayat 204-206, surat al-Baqarah:

"Sungguhpun dalam beberapa ayat ini, al-Qur'an kelihatan mencela orang yang meminta dunia semata-mata, tetapi bukanlah dia melarang kaum Muslimin mengurus dunianya. Tidak! Menuntut dunia tidak terlarang dan sengaja telah menjadi hak tiap-tiap makhluk yang hidup di atas dunia ini! Akan tetapi yang terlarang itu ialah "menuntut dunia dengan cara (jalan) yang buruk" bukan menuntutnya dengan cara yang baik, bagus dan halal. Menuntut dunia dengan cara yang tersebut belakangan ini sedikit juga tidak berlawanan dengan taqwa kepada Allah bahkan akan menambah taqwa itu pula, kata penafsir al-Manar, serta menambah memudahkan orang mempelajari agamanya." (H. A. Halim Hassan, et al., 1960, 2:283).

Dalam penafsirannya, pentafsir turut membandingkan sifat kesederhanaan dan moderat (pertengahan) dalam praktis tasawwuf Islam dengan pekerjaan agama yang ekstrim yang dikerjakan oleh umat yang terdahulu: "Dengan peraturan ini nyatalah perbedaan antara agama Islam dengan agama-agama lain yang lebih dahulu datang dari pada Islam, yakni agama-agama itu berpendapat bahwa: "menyiksa jasad dan mencegahnya dari segala kebaikan-kebaikan barang dunia ini, itulah asal dan asas agama-agama itu." (H. A. Halim Hassan, et al., 1960, 2:283). 


\section{Syafa'at}

Syafaat, seperti yang ditakrifkan oleh Kamus Dewan (ed. 4), ialah; kelebihan yang dikurniakan Allah kepada Rasulullah saw untuk menolong umat Baginda saw di Padang Mahsyar kelak: barang pintanya dikabulkan Allah swt dengan berkat [syafaat] Nabi Muhammad (saw). (Kamus Dewan Edisi Keempat, 2012) Syafaat juga diungkapkan sebagai wasilah bagi menyampaikan hajat dan harapan. Kitab Tafsir al-Qur'anul Karim ini banyak mengupas persoalan syafa'at yang dikaitkan dengan keimanan terhadap hari akhir dan kebenaran syafaat di akhirat. Dalam ayat 123, surah al-Baqarah dinyatakan: "Dan takuti oleh kamu akan suatu hari yang tidak dapat suatu diri menggantikan diri yang lain barang suatu jua, dan tidak diterima tebusan dari padanya dan tidak berguna kepadanya syafa'at; dan mereka tidak akan diberi pertolongan", pentafsir menghuraikan pengaruh keyakinan terhadap syafa'at, yang menurutnya kalangan yang jahil akan maqasid syariah akan menyandarkan seluruh pengharapannya terhadap syafaat tanpa menyempurnakan ikhtiar: "Diteruskannya jugalah pekerjaan itu (yang salah dan terlarang) dengan pengharapan akan mendapat ampunan di belakang hari;...ampunan yang diharap dari pertolongan orang lain, ya'ni ampunan yang akan didapati dari syafa'at orang lain, misalnya dari nabi-nabi nya (as), orang-orang saleh.

Sebagaimana yang diketahui orang: bahwa pengaruh harapan yang seperti ini amat kerasnya. Seandainya pengharapan yang seperti itu dibiarkan berleluasa, niscaya rusaklah peraturan-peraturan dunia ini, kerana dikhuatiri orang sama sekali tidak akan mau lagi melakukan perbuatan yang baik, kalau disangkanya cukuplah pertolongan orang lain yang akan menolong dan melepaskannya dari pada siksaan Allah. Keadaan yang seperti ini tidak sesuai dengan sunnah Allah (swt) yang sudah ditetapkan-Nya. Syafa'at itu sebenarnya ada, tetapi bagi orang yang sudah menanam benihnya lebih dahulu dalam dunia ini, sebagaimana yang telah diterangkan panjang lebar dalam Tafsir al-Qur'anul Karim ini." (H. A. Halim Hassan, et al., 1960, 1/328). 
Konsep syafaat ini dikaitkan dengan keputusan Tuhan di hari akhir, yang tidak menerima syafaat dan tebusan sama sekali, kerana setiap diri harus menanggung hasil usaha tangannya sendiri, tanpa dapat mengharapkan sesiapa untuk menebus dan memikulnya: "Ayat ini sudah juga disebutkan dalam ayat yang lalu, supaya pengajaran al-Qur'an itu selamanya mendapat penerimaan yang penuh dari pembaca dan pendengarnya, agar semakin hidup berjiwa meresap ke dalam diri orang yang membacanya dan juga untuk menerangkan kepada kita bahwa: di akhirat tebusan dan syafaat itu sama-sama tidak akan diterima." (H. A. Halim Hassan, et al., 1960, 1/328) [surah 2:123].

\section{Sejarah Bani Isra'il / Isra'iliyat}

Persoalan sejarah yang signifikan diangkat dalam Tafsir al-Qur'an al-Karim ini dengan mengupas pertimbangan dan buah peninjauannya dalam tafsir-tafsir klasik seperti Tafsir al-Kabir, oleh Imam al-Razi, Jami' al-Bayan dan Tarikh alUmam wal Muluk oleh Syaikh Mufassirin Abu Ja'far Muhammad b. Jarir al-Tabari, Al-Muntazam oleh Ibn al-Jawzi, dan al-Bidayah wal-Nihayah oleh Ibn Kathir. (Rujukan dari kitab-kitab tarikh yang substantif dipaparkan pada juz 1/339341). Persoalan sejarah yang dirumuskan dalam Tafsir ini mengupas tentang sejarah Bani Israil, kisah Isra'iliyat, syariat umat yang terdahulu dan silsilah kerasulan, yang memperlihatkan aspirasinya untuk "berhakim kepada sejarah" kerana pengalaman sejarah turut penting untuk menentukan haluan dan pandangan sejarah yang belakangan.

Bani Isra'il adalah suatu bangsa yang lahir dari keturunan Nabi Ya'kub (as). Al-Qur'an banyak menyingkap warisan sejarah Bani Israil dan tradisi agama dan kisah penindasannya di bawah kekuasaan Fir'aun. Ia turut memerihalkan "perilaku orang Yahudi akan kenabian, terhadap Nabi Muhammad (saw), Nabi Musa (as), dan Nabi-Nabi (as) yang lain, kelaziman mereka menyembunyikan yang haq, cara dan sikap menyembunyikan itu." Menurut pentafsir, keangkuhan dan kezaliman yang diteruskan oleh puak Yahudi hanya merendahkan martabatnya, kerana "pangkat keimanan dan ketinggian dalam agama tidak akan dapat dicapai orang-orang yang zalim." (H. 
A. Halim Hassan, et al., 1960, 1/340). Dalam kitab Tafsir ini, dipaparkan dengan jelas keangkuhan kaum Yahudi, Nasrani dan Musyrikin, dan persamaannya dengan sikap sebahagian umat Islam yang berkeras mempertahankan "sifatsifat pembantah dan berkeras kepala (mereka) dalam perkara-perkara yang batal (sesat)."

Pada tafsir surah al-Baqarah, ayat 124, yang berbunyi: "Dan ingatlah (ketika) Ibrahim (as) dicobai Tuhannya" pentafsir menghuraikan kefahaman ayat yang lahir yang menceritakan darihal ahli kitab dan keyakinan mereka terhadap al-Qur'an dan kenabian Nabi Ibrahim (as): "Sebagaimana biasanya Tafsir al-Manar mengemukakan pendapatnya dalam soal-soal yang penting, demikian juga dalam ayat ini. Katanya:

"Sesungguhnya engkau dapat melihat perkataan (Tuhan) di sini berlaku dengan ringkas dan secara isyarat sahaja. Ini menunjukkan bahwa bangsa 'Arab itu orang yang tajam fikirannya, bersih hatinya, halus fahamnya dan lemah lembut perasaannya, demikian juga ayat ini dapat pula dijadikan hujah terhadap kedua partai itu (ahli kitab dan 'Arab musyrikin). Kerana sekalian ahli kitab, sebagaimana yang telah diterangkan, sama-sama membesarkan Nabi Ibrahim a.s. serta mengi'tiqadkan kenabiannya bahkan orang Israiliyah membanggakan keturunannya kepadanya.

Demikianlah hujah-hujah al-Qur'an kepada ahli kitab untuk memperbaiki agama mereka dan meninggikan mereka padanya, karena agama Allah itu satu jua pada jauharnya." (H. A. Halim Hassan, et al., 1960, 1/338).

Perbahasan tentang sejarah Bani Isra'il dan kisah-kisah Isra'iliyat yang dibawakan dalam Tafsir ini diacu dari Tafsir Kisan al-Hisan oleh al-Tha'laby, Irshad al-'Aql al-Salim oleh Abu's Su'ud dan Ahkam al-Qur'an oleh Ibn al-'Arabi. Tafsir ini memuatkan perbincangan yang kritis tentang kitab dan syariat yang diturunkan kepada umat terdahulu, yang menurut pentafsirnya: "Sepanjang pendapat kami adalah baik kita perhatikan dan kalau perlu dikutip perkataanperkataannya sekadar untuk mendapatkan suatu perbandingan dalam soal-soal 
yang kami rasa memerlukannya dan menghajatinya." (H. A. Halim Hassan, et al., 1960, 2/8). Ibn al-'Arabi dalam tafsirnya mengungkapkan keharusan membicarakan perihal Bani Isra'il berdasarkan keterangan hadith: (Ceritakan dari Bani Isra'il dan tidak mengapa). (Ibn Kathir, 2018, 1/xviii) (Ibn al-'Arabi, Abu Bakr Muhammad b. 'Abdullah, 2006, 1/46). Dalam tafsir ayat 123, surah alBaqarah diungkapkan tentang kedangkalan dan kejahilan mereka mempertahankan nilai yang bobrok yang rusak dan keangkuhannya menolak wahyu yang diutuskan:

“Adapun orang Bani Isra'il mereka tidak hendak bergerak dan berkisar dari pendiriannya, kerana mereka banyak sekali mempercayai kifarat-kifarat yang akan menutupi dosanya, kifarat yang akan menghapuskan kesalahannya, mempercayai syafa'at Nabi Nabi (as) mereka yang amat banyak itu. Sebab itu Tuhan terus memutuskan segala tali temali pengharapan mereka itu." (H. A. Halim Hassan, et al., 1960, juz 1/339).

Turut dibahaskan adalah kesan sejarah mereka yang signifikan dalam perkembangan peradaban di Mesir dan "nikmat-nikmat yang dianugerahkanNya kepada kaum itu": "Kejahatan budi pekerti kaum Bani Israil, baik yang berhubung dengan urusan agama ataupun yang bersangkut dengan amalamalan mereka yang sudah mereka buktikan di atas papan catur penghidupan dunia." (H. A. Halim Hassan, et al., 1960, juz 1/339) Isu yang turut diutarakan adalah seputar perjuangan dan nilai pengajaran yang positif dari sifat ketahanan bangsa Isra'il, serta perbandingan dengan syariat yang termaktub dalam tradisi agamanya: "Memberikan uraian mengenai perbedaan pendapat agama Islam dan syari'at Bibel atau syariat (Nabi) Musa (as) jika benar syari'at (Nabi) Musa (as) berbentuk demikian.

Pembaca kami yang budiman manakala telah memperbandingkan syariat (Nabi) Musa (as) - berdasarkan apa yang tersurat dalam Bibel yang ada sekarang ini - yang masih dipraktekkan oleh manusia-manusia pengikutnya yang setia, menurut keterangan penyelidik-penyelidik agama, menyatakan 
kepada kita betapa perbedaan antara syariat yang di dalam Bibel tersebut dengan yang di dalam syariat Islam dewasa ini." (H. A. Halim Hassan, et al., 1960, 2/365).

Perbincangan yang dibentangkan pada ayat 124, menzahirkan upaya yang menarik dalam membahaskan sikap dan pendirian ahli kitab terhadap risalah Islam, dalam "mendirikan hujah (tuntutan) terhadap ahli kitab, yahudi keadaan mereka yang mempermain-mainkan agamanya dan keadaan mereka dalam masyarakat dengan orang mu'min. (H. A. Halim Hassan, et al., 1960, 1/339).

\section{a. Tarbiah 'alam}

Dalam tafsirnya pada surah (1) dijelaskannya tentang hubungan yang teratur antara langit, bumi dan matahari dalam pergerakan falak: "Dialah yang sudah menjadikan sekalian yang ada pada bumi ini untuk kamu." Maka oleh kerana muslihat yang hasil pada alam sufla (bumi) ini hanya teratur oleh sebab gerak falak (matahari d.l.l.) menurut kebiasaannya, sebab itu Allah mengiringi ayat yang di atas dengan firmannya: "Kemudian menuju ke langit, maka dijadikan-Nya tujuh petala langit. Dan Dia amat mengetahui dengan tiap-tiap sesuatu." (H. A. Halim Hassan, et al., 1960, 1/48) [sura (1):5].

Pentafsir turut mengutip pandangan Syaikh Tantawi Jawhari yang menghuraikan keunikan sistem cakrawala dan keseimbangan alam yang tercipta seperti yang tercantum pada tafsir surah al-Fatihah, ayat 2: "Ilmu menjadikan dan mengatur 'alam, 'ilmu ini terkandung pada (tafsiran) Rabb al-'Alamin karena itu, al-Ustaz Syeikh Tantawi Jauhari ada menerangkan dalam kitab tafsirnya: ma'na Rabb al-'Alamin "ialah mengaturkan sekalian alam". Maka tak syak lagi, pada kalimat ini termasuklah sebahagian besar dari ilmu pengetahuan. "Alam ini terbahagi dua. "Alam atas" dan "alam bawah." Sebab kita telah maklum semuanya itu perbuatan Allah (swt) yang termasuk dalam bekas rahmatNya dan pengaturNya pada sekalian alam.

Sebab itu ilmu riyadiyah (mathematics) dan tabi'ah (nature) termasuk juga pada tarbiah 'alam, disertakan ilmu pertukangan yang lain-lain, seperti 
ilmu pengukur masa, ilmu penarik, dan lain-lain. Alhasil sekalian ilmu pertukangan, ilmu penimbang, ilmu pengukur, ilmu landbouw, ilmu tabib (kedokteran) semuanya termasuk dalam Rabb al-'Alamin kerana semuanya pecahan dari tabi'iyah dan riyadiyah. Demikian juga sekalian cabang ilmu, dan pertukangan yang ada di bawah langit atau di atasnya...dari itu Syeikh Tantawy telah memberi konklusi di dalam tafsirnya: "Orang Islam belum dapat memuji Allah dengan sebenar-benarnya selama mereka belum mengetahui peraturan tabiat (nature) dan sekalian keajaiban perbuatan Allah. Manakala ummat Islam bermaksud hendak memuji Allah dengan sebenar-benarnya maka hendaklah lebih dahulu mereka mempelajari sekalian peraturan dan kehalusan kejadian sekalian makhluk." (H. A. Halim Hassan, et al., 1960, 1/48) [sura (1):5].

Perbincangan tentang alam ini dikaitkan dengan tauhid dan ketundukan kepada Tuhan yang lahir dari kefahaman dan pencerapan terhadap ayat-ayat Tuhan yang terbentang di alam malakut dan shahadah. Dalam tafsir surah 2: 103, diungkapkan bahawa kejadian alam yang luas adalah penzahiran kuasa Tuhan dan bukti keesaanNya: "Untuk menerangkan keesaan-Nya itu, banyak sekali ayat-ayat dan keterangan yang disebut-Nya seperti langit dengan keindahan cakrawalanya, bumi dengan isi-isinya." (H. A. Halim Hassan, et al., 1960, 1/57).

\section{F. Kesimpulan}

Dari analisis ringkas seputar isu-isu sosial dan sejarah dalam kitab Tafsir alQur'an al-Karim karya al-Ustaz H. A. Halim Hasan, H. Zainal Arifin Abbas dan Abdur Rahim Haitami ini dapatlah disimpulkan pengaruh yang dizahirkannya dari ideal dan faham rasional dan pemikiran moden yang digagaskan oleh Sayid Jamal al-Din al-Afghani, Shaykh Muhammad 'Abduh dan Sayid Muhammad Rashid Rida. Ia mempertautkan aliran al-ra'y dan al-ma'thur dan menggarap fahaman modernis dan klasik dalam pentafsiran. Isu-isu budaya dan sosial yang digerakkan memperlihatkan fikrah dan prinsip Islam yang rasional dan moden yang 
diketengahkan dalam mengupas isu-isu demokrasi dan syura, kebebasan, kemunafikan, nubuwwah, sejarah Bani Isra'il, tasawwuf, khittah dakwah, faham budaya, kebijakan politik, kejadian alam, fitrah, dan syafaah. Ia merupakan antara karya tafsir kontemporer yang penting dalam perkembangan aliran tafsir pada kurun ke 20 di Indonesia. Kekuatan tafsir yang dihasilkan semenjak pertengahan awal kurun ke 20 ini adalah keupayaannya mengangkat dan memperjuangkan isuisu yang menyentuh kehidupan dan perjuangan bangsa Indonesia dan aspirasi kebebasannya yang terikat di bawah pengaruh Belanda. Dalam mengolah isu-isu yang terkait dengan pemikiran sosial dan sejarah, nilai budaya, dan kebebasan akliah, tafsir ini menguatkan aliran tafsir yang diperjuangkan oleh Muhammad 'Abduh dan Muhammad Rashid Rida yang menegakkan hujah dan idealisme sosial yang ideal dalam pentafsiran. Ia menzahirkan kefahaman nas yang rasional yang dipertahankan dengan keterangan dalil al-Qur'an dan al-hadith yang berkesan, dalam usahanya menggerakkan pengaruh dan aspirasi madrasah al-Manar yang meluas di rantau ini.

\section{Daftar Rujukan}

Abdul Halim Hasan, Zainal Arifin Abbas, Abdul Rahim Haitami (1952), Tafsir alQuran al-Karim, Penang: Persama Press.

Abdul Halim Hasan et al. (1960), Tafsir al-Quranul-Karim, ed. 2, Medan: Yayasan Persatuan Amal Bakti.

Al-Baydawi, Abu al-Khayr 'Abd Allah bin 'Umar bin Muhammad bin 'Ali (1418H), Anwar al-Tanzil wa Asrar al-Ta'wil, Muhammad 'Abd Al-Rahman (ed.), Bayrut: Dar Ihya' al-Turath al-'Arabi.

Al-Mawardi, 'Ali b. Muhammad (2006), Al-Ahkam al-Sultaniyah wal Wilayah alDiniyah, Qahirah: Dar al-Hadith.

Al-Qurtubi (2006), Al-Jami' li Ahkam al-Qur'an. 'Abd Allah bin 'Abd al-Muhsin alTurkiy (ed.), Bayrut: Mu`assasat al-Risalah.

Al-Shawkani, Muhammad ibn 'Ali ibn 'Abd Allah (1414H), Fath al-Qadir, Bayrut: Dar al-Kalim al-Tayyib.

Al-Tabari, Abu Ja'far Muhammad ibn Jarir (1420H), Jami' al-Bayan fi Ta'wil alQur'an, Ahmad Muhammad Shakir (ed.), Bayrut: Mu'assasat al-Risalah.

Freedom and Justice Party (FJP) (2011), "Election Program, The Freedom and Justice Party, Egypt", dipetik dari Marwan Bukhari "Revolusi Pasca Islamisme-Bahagian II" 
http://www.marwanbukhari.com/2011/12/revolusi-pascaislamisme.html, diakses 31 Dis 2011.

Hamka (1966), Kenang-Kenangan Hidup, Kuala Lumpur: Pustaka Antara.

Ibn al-'Arabi, Abu Bakr Muhammad b. 'Abdullah (2006), Ahkam al-Qur'an (HukumHukum dalam al-Qur'an). Diterjemahkan oleh Muhammad Ramzi Omar, Putrajaya: Jabatan Kemajuan Islam Malaysia (JAKIM).

Ibn Katsir, Al-Bidayah wa'l-Nihayah (2018). Diterjemahkan oleh Farid Fahruddin. Solo: Insan Kamil.

Ibn Taymiyah, Ahmad ibn 'Abd al-Halim (2004), Al-Majmu'ah al-'Aliyah min Kutub wa Rasa'il wa Fatawa Shaykh al-Islam, Riyad: Dar Ibn al-Jawzi.

Izutsu, Toshihiko (2002), Ethico-Religious Concepts in the Quran, Canada: McGill University Press.

Jasser Auda, "Is Today's Europe a Land of Islam?"

http://www.onislam.net/english/shariah/contemporary-issues/critiquesand-thought/453514-is-todays-europe-land-of-islam.html?Thought=, diakses 17 Jan 2012.

J. Paul Barker (2011) "Compatible? Incompatible? A Theoretical Analysis of Islam and Democracy", e-International Relations http://www.e-ir.info/?p=9107 diakses 12 Jan 2012

Kamus Dewan Edisi Keempat, http://prpm.dbp.gov.my/Search.aspx?k=syafaat, diakses 22 Jan 2012.

Muhammad Asad (1987), Sebuah Kajian tentang Sistem Pemerintahan Islam. Diterjemahkan oleh Afif Mohammad, Anwar Haryono dari Minhaj al-Islam fi al-Hukmi (Islamic Constitution Making). Batu Caves: Thinker's Library.

Rida, Muhammad Rashid (1922), Al-Khilafah wa al-Imamah al-'Uzma, Cairo: alManar Press.

Rida, Rashid (1947M/1366H), Tafsir al-Manar, Kaherah: Dar al-Manar. 